DOI: $10.22363 / 2312-8674-2017-16-1-131-133$

\title{
ПРОМЕЛЬКНУВШИЙ МЕТЕОР...
}

Светлой памяти

профрессора С.Ф. Гребениченко

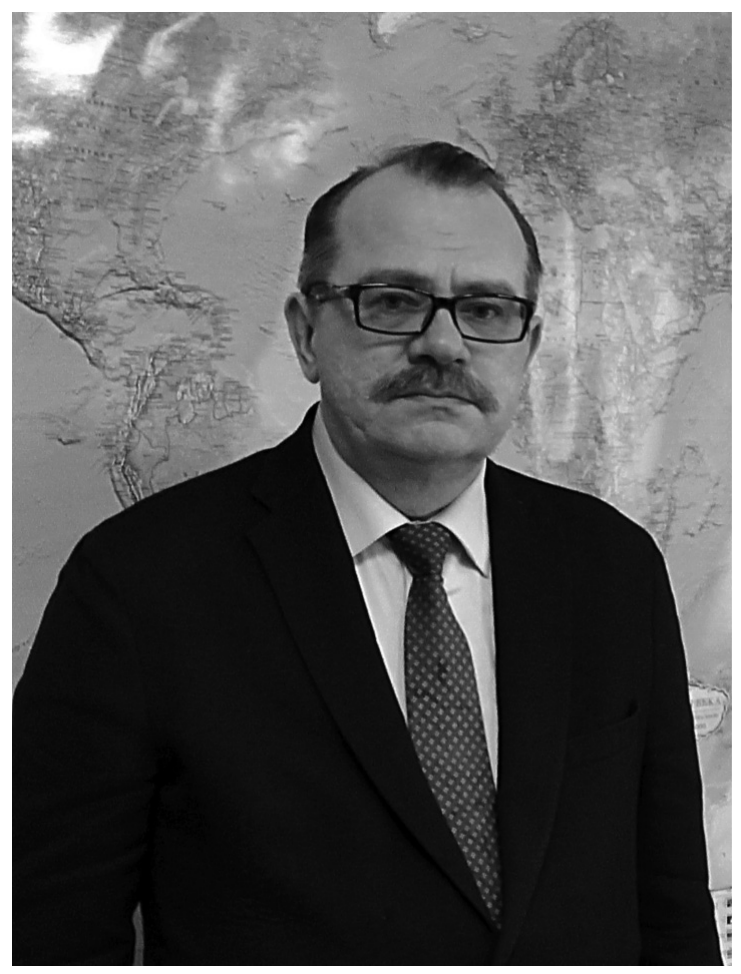

Не стало Сергея Федоровича Гребениченко - нашего коллеги, доктора исторических наук, профессора кафедры истории России РУДН. В это трудно поверить, зная его как энергичного, доброго, отзывчивого, заботливого и в тоже время принципиального товарища.

Сергей Федорович родился 19 октября 1962 г. в Камчатской области в семье служащих. После окончания средней школы поступил на исторический факультет Дальневосточного государственного университета. В 1987 г. защитил кандидатскую диссертацию в Московском государственном университете им. М.В. Ломоносова под руководством крупнейшего ученого в области источниковедения И.Д. Ковальченко. В 1996 г., после окончания докторантуры Института российской истории РАН, блестяще защищает докторскую диссертацию в диссовете по историческим наукам при кафедре истории России 
факультета гуманитарных и социальных наук РУДН, а через полтора года избирается по конкурсу профессором этой же кафедры.

До прихода в большую науку С.Ф. Гребениченко прошел серьезную школу государственной работы: заведующий лабораторией криминалистики и криминологии ДВГУ; старший научный сотрудник Академии общественных наук при ЦК КПСС; консультант ЦК КПСС; помощник члена ЦК КПСС - Председателя Центральной Контрольной Комиссии КП РСФСР; референт Заместителя председателя КГБ СССР; старший референт Председателя Комитета по работе с личным составом Министерства обороны РФ; старший научный сотрудник Института Российской истории РАН; заведующий информационносоциологического сектора Российской академии государственной службы при Президенте РФ; руководитель аппарата Председателя Комиссии по городскому хозяйству и жилищной политике Московской городской Думы.

Его научная и педагогическая деятельность охватывала широкий круг исторических проблем и была неразрывно связана с интересами кафедры истории России. В результате им был предложен и внедрен целый ряд новых подходов в исторической науке и историческом образовании. Научные интересы профессора С.Ф. Гребениченко лежали в области экономической истории, теории и истории международных отношений со странами дальнего и ближнего зарубежья, социальных проблем современной России, а также формирования ее властных структур. Им опубликовано более 300 научных трудов, в числе которых 25 монографий и учебных пособий.

Научная деятельность Сергея Федоровича активно продолжалась до последних дней его жизни. В частности, только в одном 2016 г. им было опубликовано более 20 актуальных научных и методических статей в ведущих российских журналах. Профессором было подготовлено 2 доктора и 21 кандидат исторических и социологических наук, среди которых 7 представителей зарубежных государств.

Кроме этого, в прошедшем году под научным руководством Сергея Федоровича Гребениченко была успешно защищена докторская диссертация, имеющая исключительно важное актуальное, научное и практическое значение на тему: «Исторический опыт сотрудничества Российской Федерации и Республики Казахстан в сфере экономической безопасности в 1990-е - 2010-е годы», подготовленная известным дипломатом и ученым Сагиндиковым Рустемом Елеусиновичем, а также 2 кандидатские диссертации наших аспирантов.

До настоящего времени С.Ф. Гребениченко являлся членом диссертационного совета по историческим наукам при кафедре истории России РУДН, в течение многих лет выполнял обязанности члена редколлегии журнала «Вестник РУДН. Серия: История России». И везде его научный авторитет был непререкаем, а профессиональный опыт - бесценен.

Большую плодотворную работу он творчески сочетал с учебным процессом на факультете гуманитарных и социальных наук университета. Предме- 
том его особой заботы и гордости было преподавание магистрам-историкам ряда актуальных курсов (в числе которых был, в частности, курс «Современная история исторической науки»), которые отличались академизмом и высоким профессионализмом.

Активная работа профессора С.Ф. Гребениченко позволила кафедре истории России развить широкие и прочные связи с ведущими университетами Москвы - МГУ им. М.В. Ломоносова, МГИМО, Государственным университетом по землеустройству, Российским государственным университетом нефти и газа им. И.М. Губкина и др.; а также Московской городской Думой, рядом редколлегий ведущих научных изданий, входящих в перечень ВАК Министерства образования и науки РФ, в частности международным журналом «Информационное общество», федеральным журналом «Социальногуманитарные знания» и др., в которых он участвовал на правах члена редколлегии. Профессор С.Ф. Гребениченко был избран действительным членом (академиком) Российской академии естественных наук по отделению «Сословие и национальные традиции», где проводил исключительно важную работу, обеспечивая факультету гуманитарных и социальных наук, кафедре истории России весомый авторитет и научную значимость.

Одновременно Сергей Федорович активно участвовал на правах членства в Российской ассоциации «История и компьютер», российском обществе социологов, международном союзе профессиональных журналистов и др.; являлся соруководителем и разработчиком 8 федеральных опросов общественного мнения, научным редактором «Вестника» института социальных инициатив.

Сергей Федорович Гребениченко был полон дальнейших планов, связанных с научной и педагогической активизацией факультета гуманитарных и социальных наук, кафедрой истории России, написанием нового учебника и завершением монографического издания, деятельным участием в подготовке методических пособий, а также реализацией своих личных начинаний.

В расцвете творческих сил ушел из жизни известный ученый, талантливый организатор профессионального исторического образования и прекрасный человек. В памяти коллег, друзей и учеников Сергей Федорович останется глубоко порядочным, честным, доброжелательным и отзывчивым человеком.

Деканат факультета гуманитарных и социальных наук РУДН, коллектив кафедры истории России, диссертационный совет по историческим наукам выражают глубокое соболезнование в связи с безвременной кончиной академика Сергея Федоровича Гребениченко. Его светлый образ навсегда останется в наших сердцах.

(C Редколлегия журнала, 2017 